\title{
SUSTAINABLE LOGISTICS PLATFORM IN A REGIONAL BRAZILIAN AIRPORT
}

\author{
O.F. LIMA Jr${ }^{1}$, E.W. RUTKOWSKI ${ }^{2}$, C.C. DE CARVALHO ${ }^{1} \&$ J.C.F. LIMA ${ }^{2}$ \\ ${ }^{1}$ Geotechnics and Transportation Department, FEC UNICAMP, Brazil. \\ ${ }^{2}$ Sanitation and Environmental Issues Department, FEC UNICAMP, Brazil.
}

\begin{abstract}
The aim of this paper is to design a sustainable logistics platform concept based on different applications of global airport logistics platforms and industrial ecology principles. This concept has been developed for a southern Brazilian application [Campinas Metropolitan Region, São Paulo state]. The design guidelines establish a balance between the logistics activities and the environmental constraints on business viability.

Keywords: airport logistics platforms, Brazilian logistic platforms, Campinas logistic platform, environmentally sustainable, freight villages, industrial ecology, sustainable logistics platform.
\end{abstract}

\section{INTRODUCTION}

The market economy, with its just-in-time production system and globalized supply chains, promoted the development of logistics and a variety of specialties such as urban logistics.

Increase in urban population density leads to an increased need for urban distribution logistics operations, which brings more truck traffic on to the streets, containers moving in unsuitable locations, increased carbon emissions, higher levels of noise pollution, cargos thefts and, as a consequence, higher delivery costs.

Four relevant agents are affected: the logistics operators, urban residents, government and environment. The logistics operators see their efficiency reduced as increased traffic levels hinder access to routes and destinations, increase traffic congestion undermine schedules and compromise their level of service. Urban residents have their quality of life negatively affected by pollution and truck movements interfering in their working and living areas. The government has great difficulty in regulating and minimizing the impacts of this process without jeopardizing the continuity of economic activities associated with it [1]. The environment suffers from air pollution and noise caused by fleet increase.

Such problems have contributed to the improvement from 'cargo distribution centers' to 'logistics platforms'. A logistics platform is defined as a strategically situated site, encompassing several logistics activities, with a large transportation infrastructure that provides competitive advantages and enhances the logistics activities of the participants engaged in the companies business. This platform also generates significant number of jobs [2].

In the context of current globalization given by the geographical extent and the territory organization changes, it is important to develop logistic sites that meet the needs of companies from the suppliers to the customers, reducing costs and speeding the flow of information and goods [3].

The literature review on logistics platforms and multimodes terminals emphasizes the importance of an airport. With the increasing complexity of supply chains, Cappa [4] notes, 'large companies use air transport and cargo hub airports, integrated logistics and industrial operations are part of their corporate strategies to expand the marketing of goods'. Thus airport based logistics platforms are an alternative to meet the demand for greater reaction speed in the logistics supply chain.

An airport based logistics platform adds competitive advantage to air mode by integrating it to others modes, speeding operations and distribution of loads. Its installation nearby or even inside an airport site gives the differential. This type of platform gives greater agility and better structure for

(C) 2010 WIT Press, www.witpress.com

ISSN: 1743-7601 (paper format), ISSN: 1743-761X (online), http://journals.witpress.com

DOI: $10.2495 /$ SDP-V5-N2-163-174 
products and perishable goods besides more security for the transportation of merchandise with higher added value. The air mode enables not only quicker and safer transportation of seasonal goods, but also the goods to reach markets with awkward accessibility and reduces distance as well $[4,5]$.

As the logistics platforms gain productive activities and social, environmental and economic services, they have great potential both to optimize activities and processes and to avoid or minimize environmental impacts.

Despite growing environmental concerns in business management, environmental initiatives are still not commonly found in the development of a logistics platform. Some specific initiatives do exist in relation to water reuse, wastewater treatment, recycling or energy optimization. These are important actions as they improve the environment and minimize losses, and might induce a different economic perspective: environmental expenditures as an investment instead of costs.

The industry implanted into a logistics platform integrates and has a better control from production to post-production activities, distribution and technical assistance. The integration can be extended to the supply chain, attracting suppliers to base themselves inside the platform as well. This tendency to improve company inter-relationships is one of the principles of industrial ecology, a fundamental concept for the sustainability of productive activities.

This paper aims to develop, based on the precepts of industrial ecology, the concept of sustainable logistics platform for southeast Brazil (Metropolitan Region of Campinas/SP) and to establish design guidelines aiming to strike a balance between logistics activities and environmental constraints. In order to construct the concept, the authors adopted the building theory methodology, proposed by Seuring et al. [6], and a critical review of literature [7].

The concepts of different logistics platforms available both in literature [8-12]; and in practice were analyzed and compared. From this critical analysis, a proposition was constructed. The design guidelines were also established through a critical analysis from theoretical models and existing facilities.

\section{INDUSTRIAL ECOLOGY}

Sustainable development was brought to the international debate by the United Nations and emphatically announced in 'Our Common Future' as: '[...] a process of change in which the exploitation of resources, the direction of investments, the orientation of technological development, and institutional change are all in harmony and enhance both current and future potential to meet human needs and aspirations' [13]. For Manzini and Vezzoli [14] this definition highlights the need to review the pattern of existing development and aims to achieve systemic conditions at the regional and global levels.

In 1989, for the debate on sustainable development and its instrumentation, Frosch and Gallopoulos [15] published the article Strategies for Manufacturing, in Scientific American, where they stated 'that the traditional model of industrial activity - in which individual manufacturing processes take in raw materials and generate products to be sold plus waste to be disposal of - should be transformed into a more integrated model: an industrial ecosystem. [...]. An ideal industrial ecosystem may never be attained in practice, but both manufactures and consumers must change their habits to approach it more closely if the industrialized world is to maintain its standard of living - and the developing nations are to raise theirs to a similar level-without adversely affecting the environment'. This article became one of the most important references for the construction of the industrial ecology concept.

The principles of industrial ecology brought new ways for analyzing productive processes, guided by ecological concepts: ecosystem metabolism, interconnections and organisms functionality. The linear industrial activity perception - input of raw material and output of finished products and waste - is replaced by an integrated production processes concept, where the energy and materials consumption are optimized and shared by different industries. The material cycles tend to be closed with the waste of one process serving as raw material for another one. The industrial system, similar to the natural ecosystem, basically consists of material, energy and information flows and also depends on 


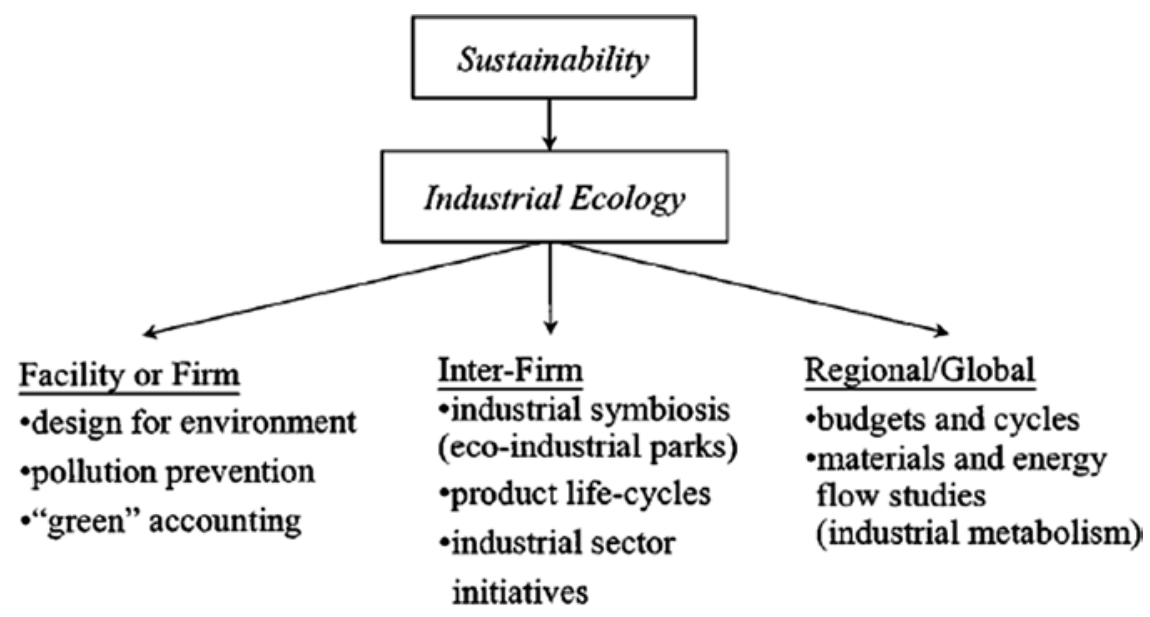

Figure 1: Industrial ecology operates at three levels [17].

resources and services provided by the biosphere. The word industrial in industrial ecology alludes to all human activities in a modern technological society, from agricultural activities to tourism activities or health services.

According to Erkman et al. [16], the main precepts of industrial ecology are

- to optimize resource use;

- to close material cycles;

- to minimize emissions;

- to reduce the quantities of materials used in activities;

- to reduce or eliminate dependence on non-renewable energy sources.

Chertow [17] comments that an industrial project based on industrial ecology has three scales of operation, represented in Fig. 1:

- within the company, for example, design for the environment;

- between companies, for example, industrial symbiosis;

- on a regional scale, for example, studies of industrial metabolism.

Industrial ecology makes possible activity scales that go beyond the corporate environmental management strategies. It may well induce changes in industry dynamics on a regional scale. Peck [18] emphasizes that industrial ecology directs business to a new paradigm, which emphasizes the policies, technologies and management systems of a more cooperative production process.

Over the last two decades of the 20th century, some industrial ecology proposals have been implemented - Kalundborg in Denmark and eco-parks in the USA and Netherlands.

Kalundborg, an industrial city on the Danish west coast, is considered a classic example, because in 1961, it united the interests of the local community with developers of a new oil refinery to ensure its future supply of drinking water from the waters of Lake Tiss $\varnothing$. The local authorities assumed responsibility for the construction of the pipeline and the refinery paid for it. From there, the community negotiates with other industries and shapes a Kalundborg interconnected network of production ([19], shown in Fig. 2).

Lowe [20] divided eco-industrial projects in three categories:

- Eco-industrial park: an industrial park developed and managed as a real estate development enterprise and seeking high environmental, economic and social benefits as well as business excellence. 


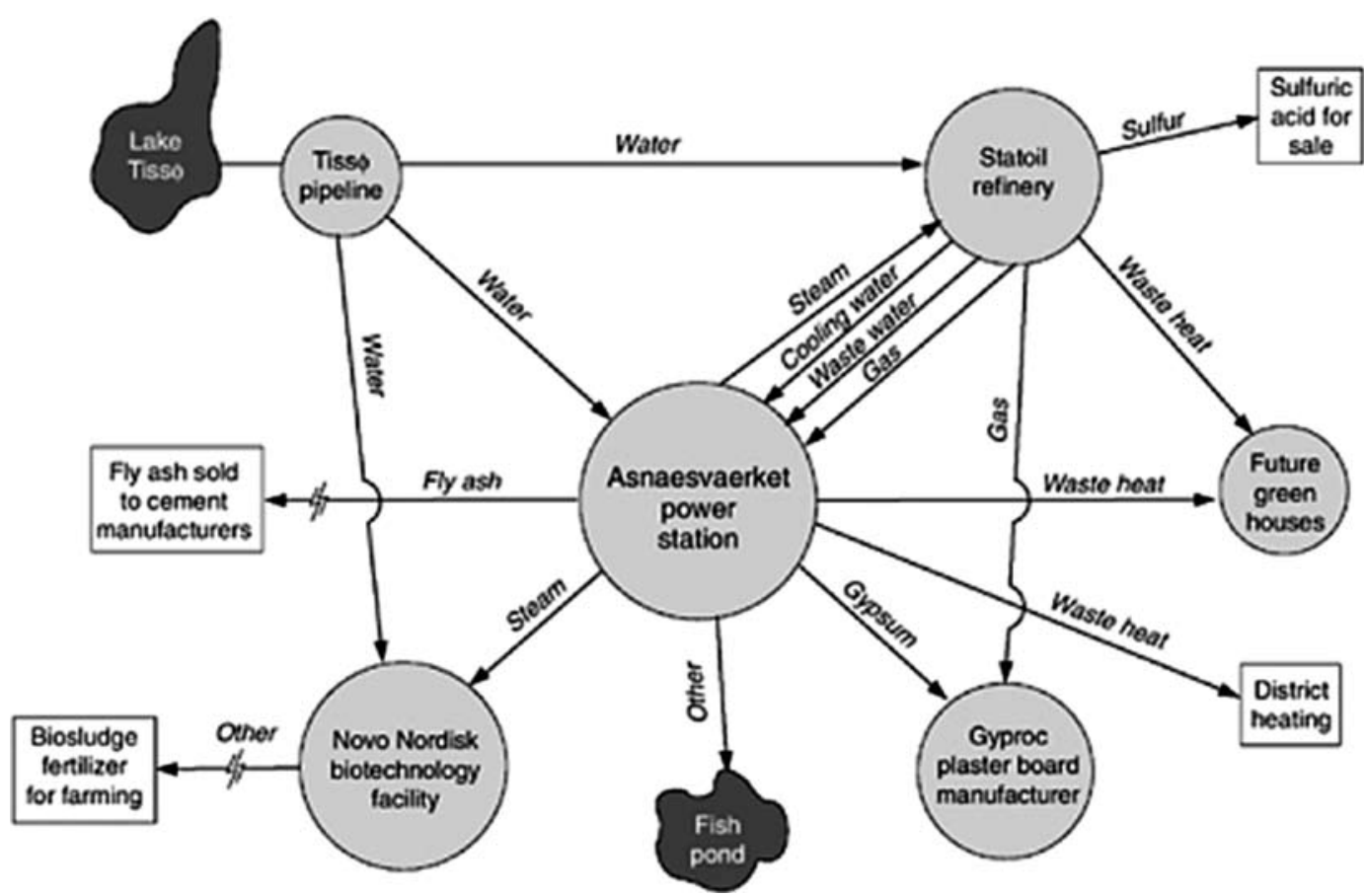

Figure 2: Network inter-connectivity production in the city of Kalundborg, DK [21].

- By-product exchange: a set of companies seeking to utilize each other's by-products (energy, water and materials) rather than disposing of as waste.

- Eco-industrial network: a set of companies collaborating to improve their environmental, social and economic performance in a region.

An eco-industrial park is an enterprise managed as a condominium. Veiga and Magrini [22] consider this model 'an initiative that seeks to achieve sustainable development by integrating issues such as economic, environmental and social responsibility from corporation and communities. It may result in jobs number and quality increase and sustainable communities, contributing to reduce pollution and waste while increasing for the companies both market insertion and opportunities for new business'. Lowe [20] from the Indigo Development Group considers that these condominium strategies should deal with different aspects - from natural resources use to neighborhood - described in Table 1 [15].

Considering the multiple configurations of the logistic platforms, this work adopts the eco-industrial park model as the aim for a Sustainable Logistic Platform.

\section{LOGISTICS PLATFORM}

The first concept of logistics platforms appeared in France in the 1960s due to advances in studies of management operation [23]. The initial goal was to reduce the disorderly flow of goods distributed by cargo terminals in big cities outskirts. The study of logistics sites starts in order to concentrate and optimize the distribution and reduce logistics costs [24].

The logistics locations were organized in three main groups, according to Collin [25]:

- Logistics Site: a well-defined region under the intervention of only one logistic operator;

- Logistics Zone: a well-defined region under the intervention of several operators in intermodal logistics and with the ability to group multiple logistic sites; 
Table 1: Strategies for designing an eco-industrial park (EIP) [15].

\begin{tabular}{|c|c|c|}
\hline Aspects & Premises & Strategies \\
\hline \multirow[t]{5}{*}{ Natural resources } & $\begin{array}{l}\text { Integration into } \\
\text { natural systems }\end{array}$ & $\begin{array}{l}\text { Select the site through the ecological carrying capacity } \\
\text { assessment } \\
\text { Minimize local environmental impacts - integrating } \\
\text { the EIP to the local landscape, the hydrologic settings } \\
\text { and the ecosystem } \\
\text { Minimize contributions for global environmental } \\
\text { impacts }\end{array}$ \\
\hline & Energy systems & Maximize energy efficiency \\
\hline & & $\begin{array}{l}\text { Achieve higher efficiency through inter-plant } \\
\text { energy flows }\end{array}$ \\
\hline & & Use renewable sources extensively \\
\hline & Water & Design the rational use of water \\
\hline \multirow[t]{4}{*}{ Waste } & $\begin{array}{l}\text { Materials flows } \\
\text { and waste }\end{array}$ & $\begin{array}{l}\text { Emphasize cleaner production and pollution } \\
\text { prevention }\end{array}$ \\
\hline & $\begin{array}{l}\text { Management } \\
\text { for the whole site }\end{array}$ & $\begin{array}{l}\text { Seek maximum re-use and recycling of materials } \\
\text { amongst EIP enterprises }\end{array}$ \\
\hline & & Reduce toxic materials risks \\
\hline & & $\begin{array}{l}\text { Link the EIP tenants to neighborhood companies } \\
\text { for resource exchanges and recycling networking }\end{array}$ \\
\hline Building & $\begin{array}{l}\text { Construction- } \\
\text { rehabilitation }\end{array}$ & $\begin{array}{l}\text { Follow the best environmental practices in materials } \\
\text { selection and building technology }\end{array}$ \\
\hline \multirow[t]{3}{*}{ Management } & Effective & Keep a mix of companies for by-products exchanges \\
\hline & management & $\begin{array}{l}\text { Support environmental performance improvement } \\
\text { for individual companies and the whole EIP }\end{array}$ \\
\hline & & $\begin{array}{l}\text { Operate a information site for inter-company } \\
\text { communications, information on local } \\
\text { environmental conditions and for feedback } \\
\text { on EIP performance }\end{array}$ \\
\hline \multirow[t]{7}{*}{ Neighborhood } & $\begin{array}{l}\text { Integration } \\
\text { to the host } \\
\text { community }\end{array}$ & $\begin{array}{l}\text { Benefit the local economy and communities - training } \\
\text { and education programs, community business } \\
\text { development and collaborative urban planning }\end{array}$ \\
\hline & & Develop housing for EIP companies' employees. \\
\hline & & $\begin{array}{l}\text { Create a community strategic plan for reducing } \\
\text { the wastes flux }\end{array}$ \\
\hline & & $\begin{array}{l}\text { Develop a effective regional by-product exchange, } \\
\text { providing markets for materials discarded as waste }\end{array}$ \\
\hline & & $\begin{array}{l}\text { Strength economic development planning to encourage } \\
\text { businesses fitting the EIP profiles }\end{array}$ \\
\hline & & $\begin{array}{l}\text { Mobilize educational resources to help the community } \\
\text { businesses and government actions to increase energy } \\
\text { efficiency and pollution prevention }\end{array}$ \\
\hline & & $\begin{array}{l}\text { Finance EPI development costs through public-private } \\
\text { partnership }\end{array}$ \\
\hline
\end{tabular}


- Logistics Hub: an ample space not very well defined that concerted logistics activities, various logistics sites and logistics zones.

The logistics platform was classified as a logistics zone and received different denominations, such as, plateformes logistiques publiques (public logistic platform), distriport, distripark, interporto, freight village, centrales integradas de mercancias (merchandises integrated center) and park logistic center [18].

Logistics platform is a specific area where several activities such as transportation, logistics and distribution of national or international transit merchandise are realized. This infrastructure is a modern alternative to solve the problems caused by the increased flow of vehicles circulating in a city because of the intensified demand of goods distribution [26]. These platforms involve alliances between organizations responsible for transport services, warehousing and distribution that can generate significant reductions in urban traffic, environmental pollution and social problems [12]. In 1992, Europe consolidated an European Association of Freight Villages known as EUROPLATFORMS. This association brought a broad and complex concept of logistics platforms: 'a defined area within which different operators realize all activities related to transportation, logistics and distribution of goods, both for the national and international transit. These operators can be owners or tenants of the buildings, equipment, facilities (warehouses, storage areas, workshops) that are built and operating within the condominium. A platform should have a system of free competition for all the companies concerned interested in performing the activities described above and provide common services for people and the users'vehicles. It is compulsorily managed by a single public, private or mixed entity' [21].

Regardless of its classification and the modes present in the logistics platform, its main purposes are to increase organization efficiency, being formed by a group of companies in either a region or a state or a country, to create jobs, to improve the service value and service timing and to increase competitiveness among partners. According to Boudouin [27], the investments in a logistics platform can be divided in public and private investments. The public investments generally focus on areas of land development, transport infrastructure implementation and, eventually, in leasing buildings to service companies and operators. The private investment, on the other hand, focuses on sites construction, where goods are handled and services delivered.

Taniguchi and Van der Heijden [28] believe that logistics platforms are the means to increase cooperation in transportation systems, which contributes not only to carbon dioxide emission reduction, but also to reduce the distances traveled by delivery vehicles. Consequently, the platforms reduce environmental impacts.

\subsection{European logistics platforms}

The majority of European logistics platforms are public initiatives with the exception of pioneering experiences, such as Garonor and Sogaris, which present characteristics of a private initiative. In the public initiatives the government is responsible for design plans, goals, investment guidelines and development, and also for coordinating and managing the logistics platforms. However, regardless the different types of initiatives, the logistics platforms are part of national development plans for transportation terminals [29].

Another striking feature of European logistics platforms are the intermodality. They include in theirs structure at least two different modes of transportation enabling the adoption of logistics network policy, a policy that encourages interaction, partnerships and cargo flows between the European continent and other continents [25, 30].

Nowadays the best known European logistics platforms are the logistics activities zones (ZAL), $P L A Z A$ - the logistics platform of Zaragoza (Spain), the Interporto Campano - the logistics platform of Nola (Italy), Sogaris Enterprise - various logistics platforms in France, the freight village in the 
UK, the GVZ (Guterverkehrszentren) - the logistics platforms in Germany and the distriparks in Belgium, Netherlands and Luxembourg [25]. Although they all develop logistics activities, they have subtle differences in concept or management.

The port of Barcelona accommodates the ZAL with the highest economic activity in Spain. It is a multimodal center of distribution and logistics and is considered the main Mediterranean port for container traffic and goods as it connects more than 400 ports around the world [25]. The Barcelona ZAL is strategically positioned with four different infrastructures to perform their logistics operations: air, rail, sea and road [31].

Another logistics platform of great importance to Spain is PLAZA, located in the city of Zaragoza, on Madrid-Barcelona road axis. PLAZA is the largest logistics zone in Europe with public management. The Government of Aragón (51.52\%), the City Council of Zaragoza (12.12\%), the Banco de Zaragoza, Aragón y La Rioja (18.18\%) and the Banco de Inmaculada (18.18\%) form the PLAZA society. PLAZA was consolidated in 2000 and is initiating the transition from the public to private domain. The road mode is the most used, despite having a railway and a barrier-free airport [2, 32].

The Italian interportos are characterized by the hierarchy of terminals, the profile of an industry with less logistics outsourcing and the focus on small and medium enterprises. They are located in the north, around Milan, Novara and Turin; in the south, in Rome, Naples and in the port of Gioia Tauro $[25,26]$. The Interporto Campano is a large logistics zone in Naples region. The management is private and has a solid infrastructure: a road transport, a railway, and airport and also serves as a dry port. The enterprise offers many activities and services that add value to goods [33].

The French platforms, according to Rosa [29] invest strongly in real estate for warehouse rents. Therefore, they attract logistics operators and industries with focus on logistics distribution. The multimodal platform in northern Toulouse is a public institution, which focuses on industrial activity. This platform was developed jointly by several partners and funded by the French state and the European Union. Other French example is the SOGARIS group, which manages private platforms [34-36].

In Germany, this enterprise presents a public-private partnership. The German platforms develop distribution activities and services, local and long distance logistics, custom services, internal security and vehicles maintenance [29].

Logistics platforms in Belgium characteristically offer a large specialized storage area and strong logistics operators. They also maintain a strong relationship with ports, attracting distribution centers of international companies. The Belgium platforms also offer an organism for protection of private interests and legal alternatives for different warehouses profiles [25].

In the United Kingdom, the Freight Villages promote intermodal transportation by providing a common service not only for carriers and logistics companies located within the platform but also for external customers. These Villages provide handling services, warehouse operation, and management for smaller companies. A British example is New Castle Freight Village [37].

\subsection{The potential of Brazilian logistic platforms}

In Brazil, the logistics platforms are a recent enterprise in an accelerated development. They emerged as an evolution of the integrated logistics centers in order to optimize the logistics processes and the supply chain activities.

The Integrated Logistics Center was designed by Brazilian public bodies as an area which should accommodate a road-rail intermodal terminal and a logistics platform capable of storage operations, distribution, containers consolidation and deconsolidation, support services and customs areas [38]. 
The Interior Custom Station (EADI) is a dry port, designed for public services of goods circulation and warehousing. It also provides custom services for all merchandise and luggage under Brazilian Internal Revenue Services, either arriving from abroad or leaving the country [38]. According to the Brazilian Custom Operators Companies Association, ABEPRA, there are 62 dry ports in Brazil. They attract distribution centers aiming to integrate the whole supply chain, through transport facilities, cargo removal from primary area (port, airport or border points) to the dry ports (secondary zone).

The first consolidated logistics platform in Brazil is the Goiás Multimodal Logistic Platform, PLMG, operating with multimodality and freight optimization [37]. The platform has a condominium concept and could be controlled by investors. The project will be implemented in four phases. The first one began in 2007 with Services and Administration Pool, road system and terminal [39].

The TERGUA Project, is another Brazilian logistics platform project, which consists of a multimodal port terminal. This project aims for multimodal integration - sea, road and rail - with a terminal exclusively for heavy loads, specialized in containers, GLP and solids bulk (fertilizer and grain). This is a project for Rio Grande do Sul, the southern state of Brazil [31].

\section{PROPOSAL}

Campinas, with one million inhabitants, is the second largest city of São Paulo state, the most industrialized state of Brazil. The Metropolitan Region of Campinas is considered the Brazilian Silicon Valley; therefore it has an important role in the national logistics industry. Viracopos International Airport handles $31.7 \%$ of total cargo imported in 2009 and $27.8 \%$ of cargo exported in 2009 from all the Brazilian air terminals. The airport is $14 \mathrm{~km}$ from Campinas center and $99 \mathrm{~km}$ from São Paulo city. From the airport, it is possible to access the major state highways.

The Viracopos International Airport serves large companies spread in 430 Brazilian municipalities: 266 cities in the Southeast (61.9\% of total); 130 cities in the South (30.2\%); 24 cities in the Northeast (5.6\%); 6 cities in the Midwest (1.4\%); 4 cities in the North $(0.9 \%)$ [40]. The importance of Viracopos International Airport, and logistics infrastructure that integrates the operations of large industrial companies, is signaled by their contribution to the growth of Brazil's GDP.

In the 1990s, the airport emerged into the international air cargo sector and became one of the main hubs in Latin America. Its logistics terminal for import and export freight occupies an area of over $81,000 \mathrm{~m}^{2}$. The infrastructure and automation of freight handling and customs clearance, developed in partnership with Brazilian Internal Revenue Services, turned Viracopos airport in a air logistics reference of national importance. Figure 3 shows the location of Campinas city, the Viracopos International Airport and the Campinas Logistic Platform (PLC).

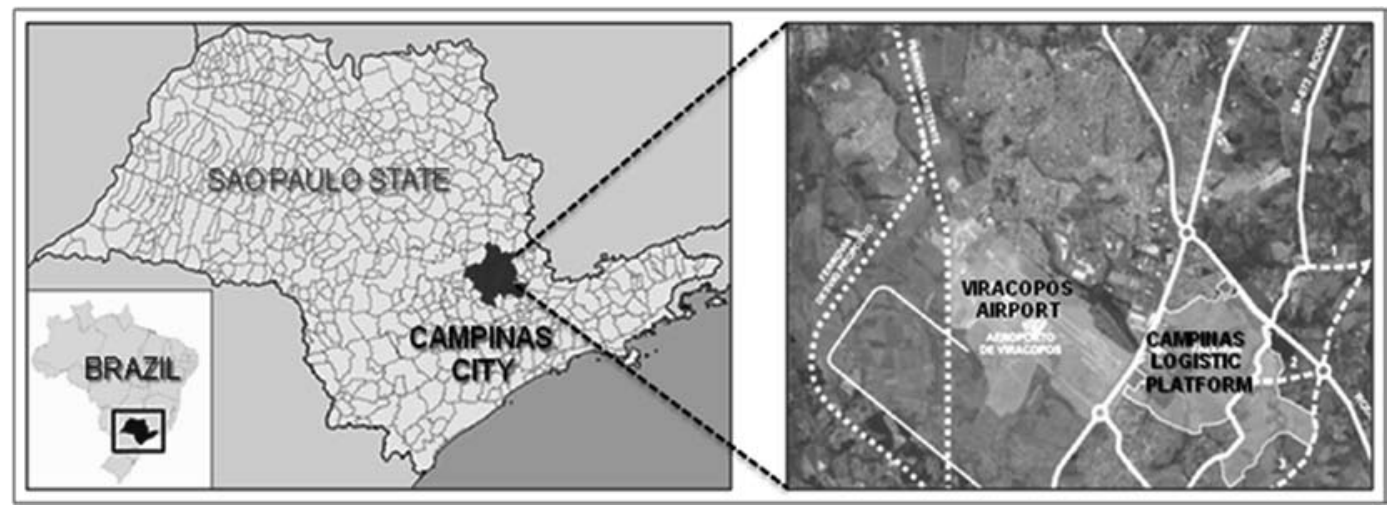

Figure 3: Location of Campinas city, the Viracopos International Airport and the Campinas logistic platform. 
The Campinas Logistic Platform (PLC) is due to be constructed in a 7,000,000,000- $\mathrm{m}^{2}$ area in front of the Viracopos International Airport. The design guidelines for this sustainable logistics platform express six interconnected topics and is summarized in Table 2 that it the compares with some examples of European logistics centers:

1. The enterprise hosts and organizes the logistics activities

An airport always causes relevant environmental and urban impacts not only locally. A neighboring logistics platform will amplify those impacts besides causing specific ones. Therefore, this kind of enterprise should keep all its activities inside its limits avoiding spreading routines to the nearby streets and avenues in order to maximize public safety.

Table 2: Summary of sustainable logistics platform aspects.

Guidelines for sustainable of PLC

(Campinas logistic platform, Brazil)

Similar initiatives in European logistic centers

The enterprise hosts and organizes the logistics activities

The enterprise becomes the local services productive arrangement secondary radiator

The enterprise flexes the expansion

The enterprise invests in research and development

The enterprise is socially responsible

The enterprise is environmentally sustainable
GVZ - Bremen freight village (Germany)

Distriparks (Belgium, Netherlands and Luxembourg)

ZAL (Spain)

PLAZA (Spain)

INTERPORTO CAMPANO (Italy)

SOGARIS GROUP (France)

GVZ - Bremen freight village (Germany)

Distriparks (Belgium, Netherlands and Luxembourg)

ZAL (Spain)

PLAZA (Spain)

INTERPORTO CAMPANO (Italy)

SOGARIS GROUP (France)

GVZ - Bremen freight village (Germany)

PLAZA (Spain)

ZAL (Spain)

SOGARIS GROUP (France)

PLAZA (Spain) - Zaragoza Logistics Center (International Center for Training and Research in Logistics - A joint venture formed between the Government of Aragón, PLA-ZA, S.A., the University of Zaragoza, with the participation of the 'Center for Transportation and Logistics' of the 'Massachusetts Institute of Technology' - MIT)

PLAZA (Spain) - specific actions (environmental rules, preservation of green areas, ecological constructions and environmental suitability of warehouses 'Eco initiatives' of enterprise Gazeley)

SOGARIS GROUP (France) - specific actions (use of cleaner technologies and optimization of resources)

GVZ - Bremen freight village (Germany)-specific actions (recycling of waste materials)

*Information not available. 
2. The enterprise becomes the local services productive arrangement secondary radiator

Viracopos airport intends to quadruple its activities over the next 10 years. For that, it is considered a primary developer of a local services productive arrangement. The airport environmental impact assessment advocates sustainability as the master key for this new era. The PLC intends to radiate a local services sustainable productive arrangement as it might gain from synergy with the airport, the highway network and the surrounding communities.

3. The enterprise flexes the expansion

The speed of change in production technologies can lead to the obsolescence of some logistics sectors. The areas defined in the PLC for the development of logistics, industrial and services activities needs, over time, to be changed both in terms of the area occupied and in the nature of its activities. The PLC, in order to maintain its cohesive logistics hub function, should be administered in such a way that it is able to accommodate those changes in the production processes, both existing and new, which might seek the condominium.

4. The enterprise invests in research and development

The PLC is, in area, one of the largest logistics platforms in the world. It is the only one, so far, that incorporated environmental sustainability into its design as a business variable. For its innovative character, the PLC will incorporate a Center of Research, Development and Innovation to establish a continuous production of knowledge and technologies and, the training of the professionals that work in the venture. The Center will be responsible for evaluating routine performance and for proposing future guidelines that preserve the business characteristics and allow the incorporation of new complementary activities.

5. The enterprise is socially responsible

The PLC will share with the surrounding communities a policy of improving regional environmental services, in order to cement the importance of environmental quality.

6. The enterprise is environmentally sustainable

The PLC has adopted sustainability as a basis for the development of activities. PLC's commitment to the environment will be responsible for minimizing the release of greenhouse gases, as well as ecological, water and energy footprints of the condominium.

\section{CONCLUSION}

Sustainability is not a major issue on all the logistics platforms studied. Most of them establish construction procedures and maintenance rules to minimize energy consumption; some are concerned primarily with water consumption. All these actions are primarily related to money saving. PLAZA, situated in a desert region, saves rainwater and rehabilitated only their side of the Aragon river riparian region. The only sustainable building is where the PLAZA administration stays.

Interporto Campano built a nearby shopping center - the Volcano Buono - totally sustainable, although the stones came from the Vesuvio outskirts - the volcano malo. The administration considered that this building compensate all environmental impacts produced by the Interporto activities.

The Campinas Logistics Platform entrepreneur decided to organize logistics activities and the complementary activities - industrial, business, services, management - in such a way that urban, regional and international logistics will be served sustainability and will be social and economically profitable.

\section{ACKNOWLEDGMENTS}

To the company $\mathrm{H} 2 \mathrm{MK}$ for financially supporting the academic research. Our deep gratitude to Kenton James Keys for revising the paper. 


\section{REFERENCES}

[1] Lima, O.F. Jr., Avaliação de Desempenho de Redes de Transportes nas Operações Logísticas do Setor de Serviços. Tese (Livre Docência), UNICAMP: Campinas, 2004.

[2] Martins, T.T., Considerações sobre Implantação de uma Plataforma Logística no Estado do Rio de Janeiro. Tese (Mestrado), Puc-Rio: Rio de Janeiro, 2006.

[3] Duarte, P.C., Desenvolvimento de um mapa estratégico para apoiar a implantação de uma plataforma logística. Dissertação de Doutorado. Programa de Pós-Graduação em Engenharia de Produção, UFRGS: Porto Alegre, 2004.

[4] Cappa, J., Análise Econômica do Aeroporto Internacional de Viracopos como Instrumento de Logística de Operações Industriais, 2008.

[5] Pedrinha, A.J., Carga aérea no Brasil: características gerais do mercado e fatores influentes, Rio de Janeiro: UFRJ-COPPE (Dissertação de Mestrado), 2000.

[6] Seuring, S., Muller, M., Reiner, G. \& Kotzab, H., Is there a right research design for your supply chain study?, Research Methodologies in Supply Chain Management, eds H. Kotzab, S. Seuring, M. Muller \& G. Reiner, Physica - Verlag: Germany, pp. 1-12, 2000.

[7] Seuring, S., Muller, M., Westhaus, M. \& Morana, R., Conducting a literature review - the example of sustainability in supply chain. Research Methodologies in Supply Chain Management, eds H. Kotzab, S. Seuring, M. Muller, \& G. Reiner, Physica - Verlag, Germany, pp. 91-106, 2000.

[8] Colin, J., Les evolutions de la logistique en Europe: vers la polarisation des espaces. I Seminário Internacional: Logística, Transportes e Desenvolvimento, Ceará, pp. 52-92, 1996.

[9] Apatjev, I.B. \& Levin, C.B., The Logistic Systems of Transport. Horhcthyuckhe tpahcnoptho: Moscou, p. 304, 2003.

[10] EUROPLATAFORMS EEIG, Logistics Centres Directions for Use. Disponível em: www. unece.org, Capturado em 16/10/2009, 2004.

[11] Dubke, A.F., Ferreira, F.R.N. \& Pizzolato, N.D., Plataformas Logísticas: características e tendências para o Brasil. XXIV ENEGEP.

[12] Ballis, A. \& Mavrotas, G., Freight village design using the multicriteria method Promothee. Operational Research. An International Journal, 7(2), 2007.

[13] WCED - World Commission on Environment and Development, Our Common Future, Oxford University Press: Oxford, ISBN 0-19-282080-X, 1987.

[14] Manzini, E. \& Vezzoli, C., Design for Environmental Sustainability, edn 1, Springer, ISBN-10: 1848001622/ISBN-13: 978-1848001626, 2008.

[15] Frosch, R.A. \& Gallopoulos, N., Strategies for manufacturing. Scientific American 261(3), pp. 144-152, 1989. doi:10.1038/scientificamerican0989-144

[16] Erkman, S., Francis, C. \& Ramesh, R., Industrial Ecology: An Agenda for the Long-term Evolution of the Industrial System, Institute for Communication and Analysis of Science and Technology (ICAST): Switzerland Geneva, 2001.

[17] Chertow, M.R., Industrial symbiosis: literature and taxonomy. Annual Review of Energy and the Environment, 25, pp. 313-37, 2000. doi:10.1146/annurev.energy.25.1.313

[18] Peck, J.S.W., Industrial Ecology: From Theories To Practice. Peck \& Associates: Ontario, Canada, 2000.

[19] Pereira, A.S., Lima, J.C.F. \& Rutkowski, E.W., Industrial ecology, production and environment: a discussion about interconnectivity of production. 1st International Workshop: Advances in Cleaner Production, São Paulo, SP, 2007. Proceedings of the 1st International Workshop on Advances in Cleaner Production, Editora UNIP: São Paulo, SP, pp. 137-137, 2007. 
[20] Lowe, E.A., Eco-industrial Park Handbook for Asian Developing Countries. A Report to Asian Development Bank, Environment Department, Indigo Development: Oakland, CA, 2001.

[21] Grann, H., The industrial symbiosis at Kalundborg, Denmark. The Industrial Green Game, National Academy Press: Washington, DC, pp. 117-123, 1997.

[22] Veiga, L.B.E. \& Magrini, A.D., Eco industrial park development in Rio de Janeiro, Brazil: Paracambi EIP. 1st International Workshop: Advances in Cleaner Production, São Paulo/SP, 2007. Proceedings of the 1st International Workshop on Advances in Cleaner Production, Editora UNIP: São Paulo, SP, 2007.

[23] European Commission, Intermodality and Transport of Goods, Brussels, 1997.

[24] Rodrigues, A.D., Plataforma Logística: Competitividade e Futuro. Revista Conjuntura Econômica Goiana, p. 65, 2004.

[25] Collin, J., Les evolutions de la logistique en Europe: vers la polarisation des espaces. I Seminário Internacional: Logística, Transportes e Desenvolvimento, Ceará, pp. 52-92, 1996.

[26] EUROPLATAFORMS EEIG, Logistics Centres Directions for Use. Disponível em: www.unece.org, Capturado em 16/10/2009, 2004.

[27] Boudouin, D., Logística-Território-Desenvolvimento: O caso europeu. I Seminário Internacional: Logística, Transportes e Desenvolvimento, Ceará, p. 105, 1996.

[28] Taniguchi, E. \& Van der Heijden, R., An evaluation methodology for city logistics. Transport Reviews 20, pp. 65-90, 2000. doi:10.1080/014416400295347

[29] Rosa, D., Plataforma logístico-cooperativa: integração horizontal das cadeias de abastecimento. Associação Nacional de Pesquisa e Ensino em transportes: Rio de Janeiro, 2004.

[30] Duarte, P., Modelo para o desenvolvimento de plataforma logística em um terminal. Um estudo de caso na estação aduaneira do interior - Itajaí/SC, Dissertação de mestrado, UFSC, 1999.

[31] Bacovis, M.M.C., II Congresso de Pesquisa e Inovação da Rede Norte Nordeste de Educação Tecnológica João Pessoa - PB - 2007. Estudo comparativo das plataformas logísticas européias $x$ brasileiras, Unidade de Ensino Descentralizado de Manaus/CEFET-AM, 2007.

[32] PLAZA, Logistics Platform of Zaragoza. http://www.plazalogistica.com/index.aspx, accessed 4/17/2009.

[33] INTERPORTO CAMPANO, http://www.interportocampano.it/, accessed 4/18/2009.

[34] EUROCENTER, www.eurocentre.fr/home/europe, Toulouse, accessed 7/28/2009.

[35] THE GUTERVERKEHRSZENTREN (GVZ) - Bremen, Germany, www.bremen.de/info/gvz/ gvzfset.html, accessed 7/28/2009.

[36] Dutra, N., et al., As plataformas logísticas e suas relações com operadores logísticos - Cenários e Tendências. Anais do XV Congresso da ANPET, Rio de Janeiro, 1999.

[37] Griffiths, J., Airport management issues. Management Development Review, MCB University Press, 0962-2519, 7(2), pp. 16-21, 1994.

[38] Dubke, A.F., Ferreira, F.R.N. \& Pizzolato, N.D., Plataformas Logísticas: características e tendências para o Brasil. XXIV ENEGEP, 2006.

[39] PLATAFORMA LOGISTICA MULTIMODAL DE GOIAS, www.plataformalogistica.go.gov. br, accessed 4/28/2009.

[40] INFRAERO - Empresa Brasileira de Infra-Estrutura Aeroportuária, O aeroporto industrial em Campinas. Encontro de Administração, Comércio Exterior, Logística e Serviços, PUC Campinas-CEA: Campinas (SP), p. 13e, 2006. 